\title{
The Pandemic of Novel Coronavirus Disease 2019 (COVID-19): Need for an Immediate Action
}

\author{
Mujib Ullah* \\ Interventional Regenerative Medicine and Imaging Lab, Department of Radiology, School of Medicine, Stanford University, \\ USA
}

\begin{abstract}
Coronaviruses belong to a large family of viruses. Coronavirus also called COVID-19 is a new disease that has not been previously identified in humans. The World Health Organization has announced that COVID-19 is a pandemic. Currently there is no specific vaccine or treatment for COVID-19. Current treatment for COVID-19 is only supportive (treating the symptoms). There are no antiviral or vaccine options currently. Therefore, it is time to bring collective efforts to treat or prevent a rapidly evolving pandemic of COVID-19.
\end{abstract}

KEYWORDS: Coronaviruses; COVID-19; World pandemic

\section{SHORT COMMUNICATION}

An outbreak of novel coronavirus disease 2019 (COVID-19), whose speed and severity trembled the world [1,2]. It is both saddening and alarming, and the World Health Organization (WHO) declared it a public health emergency of international concern $[1,2]$. The symptoms of COVID-19 illnesses have ranged from mild to severe fever, cough, and shortness of breath $[3,4]$. The entire world now faces an immediate crisis, and rapidly imposing new challenges on the health care system [2,4]. COVID-19 can transmit quite efficiently and can kill children, healthy adults in addition to the aged population with existing health problems [4]. There is an urgent need to accelerate work on treatments and vaccines for COVID-19 [2]. Even though there is a lack of functional data, the researchers sequenced the genome of the virus and developed several promising vaccine candidates for clinical trials [5]. Drug discovery can also be accelerated using digital technologies, using artificial intelligence for screening of large drug libraries, during the current crisis. Machine learning could be used to identify antivirals and other drug candidates for clinical trials.
The SARS-CoV-2, also called COVID-19 is caused by a member of the coronavirus family, which is a large family of viruses that are common in humans and in other animals, such as cats, and bats [2]. However, coronavirus has never been encountered before, and it can cause pneumonia-like symptoms including coughs, fever and breathing difficulties [2]. To halt the coronavirus epidemic, the medical community is moving quickly to find drugs. That can treat the virus $[2,6]$. As this is a viral outbreak, antibiotics are of no use $[2,6]$. Scientists must consider the development of drugs that boost the immune system [6,7]. Potential treatments for coronaviruses are antibodies and antiviral drugs [6,8]. Antibodies are the proteins that the immune system makes to fight the army of virus $[7,8]$. Researchers are currently working on creating a vaccine specifically for this virus, as well as potential treatments for COVID-19, but developing new vaccine takes time $[7,8]$. One strategy and most likely the quickest option is the use of antibodies from recovered COVID-19 patients $[9,10]$. The recovered antibodies from COVID-19 patients could be used to treat individuals with early symptoms and prevent disease further $[9,10]$.

\begin{tabular}{|c|c|}
\hline \multirow{2}{*}{$\begin{array}{l}\text { Quick Response Code: } \\
\text { 口) }\end{array}$} & $\begin{array}{l}\text { Address for correspondence: Mujib Ullah, Department of Radiology, Stanford } \\
\text { University, USA }\end{array}$ \\
\hline & $\begin{array}{l}\text { Received: April 24, } 2020 \quad \text { Published: May 01, } 2020 \\
\text { How to cite this article: Mujib U. The Pandemic of Novel Coronavirus Disease 2019 (COVID-19): } \\
\text { Need for an Immediate Action. } 2020 \text { - 2(3). OAJBS.ID.000168. DOI: 10.38125/OAJBS.000168 }\end{array}$ \\
\hline
\end{tabular}


There is a need for immediate targeted action of selfquarantine, while the pharmaceutical industry continues to work toward the development of a vaccine and therapies. There is presumably no pre-existing immunity in the population against the new coronavirus and everyone in the population is assumed to be susceptible [7]. Scientists sequenced the genome of the virus and developed several promising vaccine candidates for clinical trials [5].

It has been described that coronaviruses use spike protein, or S-protein for entry into the cells [11]. The structure of the ACE2 receptor protein, on the surfaces of respiratory cells, interact with spike protein to enter the cells (Figure 1) [11]. There are no vaccines available and there is little evidence on the effectiveness of potential therapeutic agents [12]. Nevertheless, some questions remain and not all lessons have been successful. solve the immediate problem and keep it from happening again.

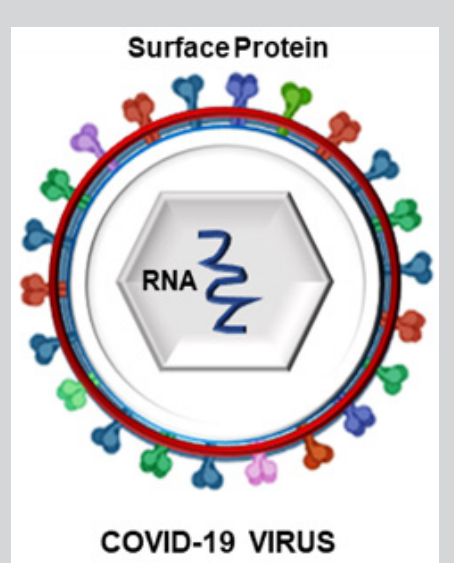

Figure 1: Illustration of COVID-19 VIRUS.

We need to build a system that can develop safe, effective vaccines and antiviral drugs on fast track for such epidemics $[12,13]$. Our entire health care system moves at a slower speed than fast-moving pathogens, part of the reason are technical, diplomatic, and investment obstacles $[12,13]$. The traditional ways for antivirals treatment are slow, we need an organized system linked with artificial intelligence to screen existing treatments and candidate molecules in an accelerated and standardized manner, without compromising patients' safety. These are the actions that leaders should be taking now. There is no time to waste.

\section{REFERENCES}

1. Gross M (2020) Virus outbreak crosses boundaries. Elsevier 30(5): 191194.

2. Del Rio C, Malani PN (2020) COVID-19-new insights on a rapidly changing epidemic. JAMA 323(14): 1339-1340.

3. Bai Y, Yao L, Wei T, Tian F, Jin DY, et al. (2020) Presumed asymptomatic carrier transmission of COVID-19. JAMA 323(14): 1406-1407.

4. Dong E, Du H, Gardner L (2020) An interactive web-based dashboard to track COVID-19 in real time. Lancet Infect Dis 3099(20): 30120-30121.

5. Wu A, Peng Y, Huang B, Ding X, Wang X, et al. (2020) Genome Composition and Divergence of the Novel Coronavirus (2019-nCoV) Originating in China. Cell Host Microbe 27(3): 325-328.

6. Zhang L, Liu Y (2020) Potential interventions for novel coronavirus in China: A systematic review. J Med Virol 92(5): 479-490.

7. Prompetchara E, Ketloy C, Palaga T (2020) Immune responses in COVID-19 and potential vaccines: Lessons learned from SARS and MERS epidemic. Asian Pac J Allergy Immunol 38(1): 1-9.

8. Sahin AR, Erdogan A, Agaoglu PM, Dineri Y, Cakirci AY, et al. (2019) Novel Coronavirus (COVID-19) Outbreak: A Review of the Current Literature. EJMO 4(1): 1-7.

9. Casadevall A, Pirofski LA (2020) The convalescent sera option for containing COVID-19. J Clin Invest 130(4): 1545-1548.

10. Law PK (2020) Emergent serum therapy and antibody medicine to counteract sudden attacks of COVID-19 and other pathogenic epidemics. Scientific Research Publishing 9(1): 1-7.

11. Walls AC, Park YJ, Tortorici MA, Wall A, McGuire AT, et al. (2020) Structure, Function and Antigenicity of the SARS-CoV-2 Spike Glycoprotein. Cell 181(2): 281-292.

12. (2020) Organization WH: Coronavirus disease 2019 (COVID-19): 45.

13. Sohrabi C, Alsafi Z, O'Neill N, Khan M, Kerwan A, (2020) World Health Organization declares global emergency: A review of the 2019 novel coronavirus (COVID-19). Int J Surg 76: 71-76. 